\title{
Bruxism and Masseter and Temporal Muscle Activity Before and After Selective Grinding
}

\author{
Bruxismo y Actividad Muscular de Maseteros y \\ Temporales Antes y Después de un Desgaste Selectivo
}

\begin{abstract}
Juan Alberto Aristizabal Hoyos'; Francia Restrepo de Mejía²; Andrés Felipe Peralta Pineda ${ }^{3}$ Y Yésica Tatiana Díaz Deossa $^{3}$; Ana María Triviño Charry ${ }^{3}$; Yury Ballesteros Oliva $^{3}$ \& Francy Yeimy Peláez ${ }^{3}$
\end{abstract}

ARISTIZABAL, H. J. A.; RESTREPO, M. F.; PERALTA, P. A. F.; DÍAZ, D. Y. T.; TRIVIÑO, C. A. M.; BALLESTEROS, O. Y. \& YEIMY, P. F. Bruxism and masseter and temporal muscle activity before and after selective grinding. Int. J. Odontostomat., 11(3):253-259, 2017.

ABSTRACT: This research aimed at determining sleep bruxism events recorded by polysomnography and masseter and temporalis muscle activity recorded by surface electromyography before and after performing a selective grinding. This study comprised three stages: 1. Pre-test (A Clinical Evaluation, an assessment through semi-adjustable articulator, a polysomnography and an electromyography); 2 . Selective grinding; 3 . Post- test (polysomnography and an Electromyography). A convenience sample of 10 subjects, with premature contact points, was assessed in a dental clinic. Subjects between 21 and 23 years were assessed. All of them had premature contacts. Eight subjects presented subsequent interferences during lateral movements. Data did not meet the criteria of normality or homoscedasticity thus non-parametric Wilcoxon test was used to compare the means of variables before and after. An average of bruxism episodes increased in stages 1 and REM but there was not a significant statistical difference in the polisomnographic recording after selective grinding. In stages 2 and 3 of sleep $26 \%$ and $54 \%$ reductions were found respectively. In stage 3 the difference between events was statistically significant. The recording of electromyographic activity before and after selective grinding showed a decrease in amplitude, length and area of the masseter and temporalis muscles. The difference was statistically significant only for temporary muscles in the length values and the right temporal area. After selective grinding the number of bruxism episodes decreased during the sleep stages 2 and 3 . The selective grinding showed a statistically significant reduction of action potentials recorded by the surface electromyography of temporal muscle.

KEY WORDS: bruxism, polysomnography, electromyography, masseter muscle, temporal muscle.

\section{INTRODUCTION}

Bruxism is associated with clinical problems, including orofacial pain, dental wear and it is related to failures in restorative dental treatments.

Nowadays, bruxism is no longer accepted as a single condition, on the contrary it is divided into two distinct types: Daytime bruxism (awake bruxism) and sleep bruxism (asleep bruxism) based on when the activity occurs. Moreover, current research methods have enabled the study of a large number of physiological systems, including brain activity, muscle activity, heart functioning and breathing that turns into the comprehension of sleep bruxism (Klasser et al., 2015). Sleep bruxism is no longer considered simply as a condition related to mechanical factors such as occlusal discrepancies (Ramfjord, 1961), or a result of psychological problems such as stress, anxiety, depression or their combination (Manfredini \& Lobbezoo, 2009). Instead, it has mainly being considered as part of a movement disorder related to sleep with a still discerned multifactorial etiology and complex multisystem physiological processes (Klasser et al.).

\footnotetext{
${ }^{1}$ Dentist, Specialist in Comprehensive Oral Rehabilitation. Undergraduate and Graduate Professor at Autonoma University of Manizales. Researcher of INSAO Research group, Colombia.

${ }^{2}$ Physiatrist, Master in Research and Educational and Social Development. Master in Neuroscience and Biology of Behavior, PhD in Social Sciences, Childhood and Youth. Research-Professor of Autonoma University of Manizales, Colombia.

${ }^{3}$ Postgraduate Residents in Oral Rehabilitation. Autonoma University of Manizales, Colombia.
} 
In 2014, the American Academy of Sleep Medicine defines bruxism as a repetitive jaw muscle activity characterized by clenching or teeth grinding and/or by bracing or thrusting of the mandible (American Academy of Sleep Medicine, 2014).

Clenching and grinding teeth is usually associated with micro-arousals during sleep, which can lead to pain in masticatory muscles and problems in the temporomandibular joint. This activity can be seen as episodes of increased muscle activity referred to clenching or to rhythmic contractions of the muscles. Repetitive grinding movements and functional hyperactivity induce traumatic injuries to the masticatory system (Kirveskari \& Jämsä, 2009).

The physiopathology of sleep bruxism is related to a rhythmic masticatory muscle activity (RMMA), which is a type of muscle activity characterized by rhythmical masticatory movements with one of two events per hour of sleep with an approximate frequency of $1 \mathrm{~Hz}$, especially in stages 1 and 2 of NREM sleep. This parafunctional masticatory activity is observed in $60 \%$ of non-bruxers and $80 \%$ of people with sleep bruxism (de-la-Hoz, 2013). About $80 \%$ of episodes of bruxism appears in groups during the transition, from third to second sleep stage, and from second to first sleep stage of non-REM sleep, that is from deep sleep stage to light sleep stage associated with microarousals (short periods from 3 to 15 seconds when a cortical activation is associated with increased activity of the sympathetic nervous system (Macaluso et al., 1998; Lavigne et al., 2008).

For clinical and research purposes a diagnostic classification system of sleep and day bruxism was suggested by an expert group which rates items as "possible", "probable" and "definite" (Lobbezoo et al., 2013). The authors of this study suggested "possible", probable and definite. "Possible" refers to sleep bruxism and awake bruxism that are based on patients' selfreports through questionnaires with or part of a clinical examination. "Probable" refers to sleep and awake bruxism that are based on patients' self-report and a clinical examination. "Definite" refers to sleep bruxism that is based on self-report, clinical examination and polysomnographic record, along with audio or video. Lastly, "definite" refers to awake bruxism that is based on self-report, clinical examination and electromyographic record preferably combined with ecological momentary assessment. This allows a true estimation from the frequency of contact of the teeth during the state of consciousness, among others (Lobbezoo et al.).
The role of occlusal interferences and occlusion in temporomandibular disorders specifically in bruxism have been controversial.

Interferences are defined as an impairment that occurs in excursive movements due to rupture of the shock of a peak top against a bottom in a lateral or protrusive movement (Ruiseco Palomares et al., 2006). In order to protect the teeth, the pattern of "avoidance" is set reflexively. A premature contact is a general term to denote any contact between an upper and a lower tooth which prevents from maximum intercuspation between the two dental arches in mandibular closure, and slides the jaw to reach at maximum intercuspation (Ramfjord \& Ash, 1966). Occlusal interference causes masticatory muscle hyperactivity and bruxism, which in turn can produce an overload of masticatory muscles, sensibility, pain and joint noise (Michelotti et al., 2005).

Carlsson et al. (2003) demonstrated in a 20 year followup research study that post-normal occlusion (Angle class II) and tooth wear in childhood could be predictors for an increased anterior tooth wear on adulthood.

In past decades, Ramfjord \& Ash and Dawson (1974) established that bruxism could be effectively treated through occlusal adjustment. Authors really believed that bruxism was caused by occlusal interferences and its cure was determined by its elimination. Although, it had never been tested, it was of great importance to clinicians who used it as a therapy with no scientific support.

Some studies have attempted to evaluate the results of treatment with some means of occlusal adjustment.

Kopp (1979) studied 30 patients divided into 2 groups of 15 participants, one group received occlusal adjustment and the other did not. Both groups were compared according to Helkimo index. The clinical dysfunction was significantly reduced during the period following occlusal adjustment with a $67 \%$ patient's improvement. This study concluded that the correlation between changes in subjective and clinical dysfunction was poor and there may be reduction of clinical signs in joint dysfunction associated with TM joint but individual variation in response was substantial.

Other authors such as Greene \& Lask (1983); Mejersjö (1984); Wedel (1988) concluded that occlusal adjustment combined with other media had positive long-term effects in patients with TMD notwithstanding 
occlusal adjustment as single treatment was not assessed in those studies (De Boever et al., 1994).

Vallon (1997) published the results of a short and long-term prospective evaluation of 50 patients with craniomandibular disorders who were treated with occlusal adjustment and other treatments. Occlusal adjustment in short-term (1 to 3 months) had a positive effect on the symptoms, but this same treatment had little effect or no effect in long term. The best result of occlusal adjustment was obtained combining other treatment approaches in long term.

A study on selective grinding as a prophylactic treatment in craniomandibular disorders was published in 1998 (Kirveskari et al., 1998). A sample of 146 patients was followed-up for 4 years. The study aimed at finding out the causal role of occlusal interferences operationally defined by Dawson. The adverse effects caused by the selective grinding were considered unfounded. This study suggested the need to study the relationship of occlusal contacts and temporomandibular disorders. If slight differences in occlusal contacts are significant factors in complex causal TMD, the role of occlusal adjustment can appropriately help to what was previously established. However, occlusal adjustment was not warranted as prophylactic treatment whereas the causal role of occlusion was clearly established in the etiology complex (Kirveskari et al.).

The objective of this research was to determine the sleep bruxism events recorded by polysomnography and the masseter muscle activity and time recorded by surface electromyography before and after performing a selective grinding.

\section{MATERIAL AND METHOD}

This quasi-experimental study comprised the following stages: 1. Pre -test (A Clinical Evaluation, an assessment through a semi-adjustable articulator, a polysomnography and an electromyography). 2 . Intervention (a selective grinding). 3. Post- test (a polysomnography and an Electromyography).

A convenience sample of 10 undergraduate dentistry students were evaluated as patients with premature contacts in a dental clinic. This sample number was due to the cost of the tests. An informed consent from participants and an authorization from
Bioethics Committee of the University were requested in order to fulfill all the requirements of the 8430 standard governing health research in Colombian territory. The analysis of occlusion was used to determine the inclusion criteria. Patients included in the study needed to have any kind of premature contact and/ or interference, anterior and occlusion Class I. Subjects with crossbites, symptoms of temporomandibular joint dysfunction or orthognathic surgery, and tooth loss were not included.

A Cadwell Easy III PSG EEG System, 32 channel amplifier (2010) was used. For polysomnography, 10/20 system was used to obtain the electroencephalographic record, and all electrodes, installed along body and that are required by the technical standard of the examination were used. The test took an average of 8 hours.

The surface electromyography was performed using a Cadwell Wave Siena console: WV 000491 6501, amplifier: 0501PX50-00-002, OR: 4 channels. This was used to measure the activity of masseter and temporal muscles. All criteria established by the technical standard for the examination were fulfilled.

Selective grinding (McHorris et al., 1985) was performed by an oral rehabilitator who was an external researcher and an expert. Two types of new burs were used, a fine and coarse football shaped diamond bur and a fine round end taper bur as well as a high-speed dental piece. Grinding was done by the subtraction method or "selective grinding", verification of the functionality of the previous guide was accomplished. The centric wears began in order to achieve a single arc of closure, effectively guided by the previous guide. This means, the coincidence between normal occlusion and centric relation. After correction of premature contacts and interference, two months were necessary to ensure the formation of new muscle engrams. After this time period, a new polysomnography and surface electromyography were performed following the protocols described above.

\section{RESULTS}

Subjects were aged between 21 and 23 years, seven subjects had received orthodontic treatment, 3 of them reported to be aware of dental clenching at night and all of them recorded class I molar relation. All subjects recorded premature contacts, and eight 
ARISTIZABAL, H. J. A.; RESTREPO, M. F.; PERALTA, P. A. F.; DÍAZ, D. Y. T.; TRIVIÑO, C. A. M.; BALLESTEROS, O. Y. \& YEIMY, P. F. Bruxism and masseter and temporal muscle activity before and after selective grinding. Int. J. Odontostomat., 11(3):253-259, 2017.

Table I. Statistical difference between the averages of bruxism before and after selective grinding.

\begin{tabular}{|c|c|c|c|c|c|c|}
\hline \multirow[t]{3}{*}{ Variable } & \multirow{3}{*}{$\begin{array}{l}\text { Mean }+/-D A \\
\text { Stage } 1\end{array}$} & \multirow{3}{*}{$\begin{array}{l}\text { IC 95\% } \\
\text { Pre } \\
\text { Post }\end{array}$} & \multirow{3}{*}{$\begin{array}{c}Z^{a} \\
2.6+/-3.63 \\
7.2+/-6.53\end{array}$} & \multicolumn{3}{|c|}{ Asymptotic significance (bilateral) } \\
\hline & & & & $0.1-5.19$ & & \\
\hline & & & & $2.53-11.87$ & -1.0090 & 0.108 \\
\hline \multirow{6}{*}{ Amount of bruxisms } & Stan?? & Pre & $26.6+/-23.69$ & $9.65-43.55$ & r14 0 & 0.475 \\
\hline & stage 2 & Post & $19.7+/-15.19$ & $8.84-30.56$ & $-0.114 \mathrm{C}$ & 0.415 \\
\hline & Stage 3 & Pre & $18.4+/-14.9$ & $7.74-29.06$ & & \\
\hline & stage 3 & Post & $8.4+/-3.75$ & $5.72-11.08$ & $-2.003 \mathrm{C}$ & $0.009^{\times}$ \\
\hline & ae & Pre & $44.8+/-22.53$ & $28.68-60.92$ & ( $83 h$ & ( 107 \\
\hline & REIVI stage & Post & $55.1+/-42.23$ & $24.89-85.31$ & -0.8310 & $0.40 r$ \\
\hline \multirow{2}{*}{ Micro-arousals } & & Pre & $21.8+/-9.47$ & $15.02-28.58$ & $-0205 \mathrm{~b}$ & 837 \\
\hline & & Post & $23.4+/-6.98$ & $18.41-28.39$ & -0.2050 & 0.031 \\
\hline
\end{tabular}

Differences in polysomnographic variables before and after occlusal adjustment. ( ${ }^{*}$ ) $\mathrm{P}<0.01$ (a) Wilcoxon signed-rank test. (B) Based on negative values. (C) Based on the positive values.

Table II. Quantitative measures of EMG temporary (Temp) and masseter (Mas ) of patients before and after occlusal adjustment.

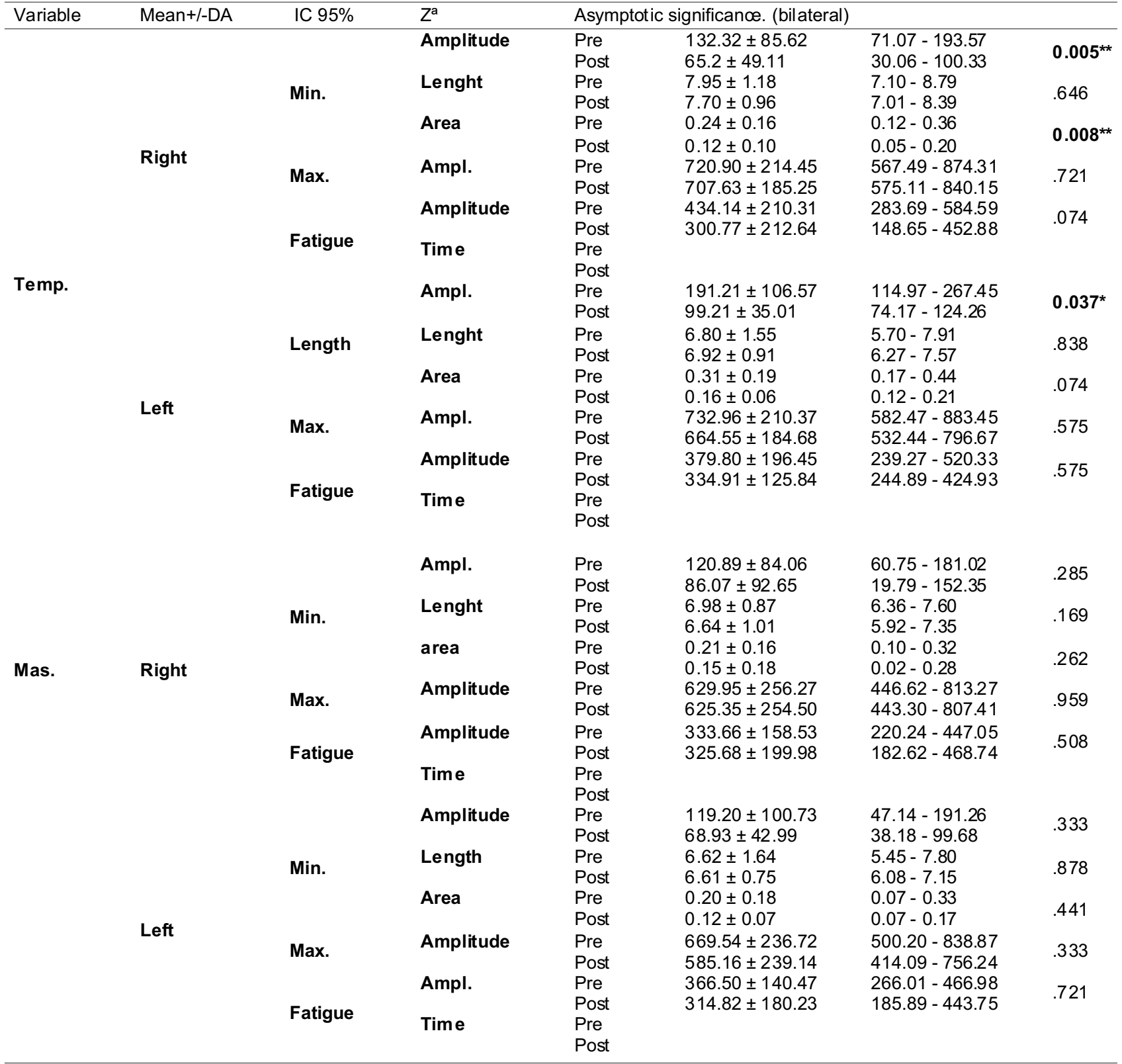


had subsequent interference during lateral movements. Criteria of normality and homoscedasticity were checked to determine if there were statistically significant differences between the samples obtained before and after the test. The Shapiro - Wilk test was used due to the amount of less than 50 observations. The variables did not meet the criteria of normality or homoscedasticity, hence a non- parametric Wilcoxon test was used to compare the means between the variables before and after.

The polysomnographic recording after grinding showed an average increase of bruxism episodes of stage 1 and REM with no statistically significant difference.

In sleep stages 2 and 3 reductions of $26 \%$ and $54 \%$, respectively were found. In stage 3 the difference between events was statistically significant (Table I).

Recording of electromyographic activity before and after selective grinding showed a decrease in amplitude. duration and area in the masseter and temporal muscles. The difference was statistically significant only for temporary muscles in the amplitude values and for the right temporal muscle in the value area (Table II).

\section{DISCUSSION}

Although the mechanism of sleep bruxism can be associated with multiple factors, the occusal factor should still be considered. Premature contacts indicate a possibility of an increase in muscle activity during sleep bruxism and some type of occlusion can play an important role even if bruxism is regulated by the central nervous system (Sugimoto et al., 2011).

Kardachi et al. (1978) concludes that the adjustment of the occlusion, on average, does not eliminate sleep bruxism. Ingervall \& Carlsson (1982) studied muscle activity before and after removal of occlusal interference and concluded that from an epidemiological point of view it is likely that many people may be muscularly well adapted to occlusal interferences and temporomandibular dysfunction. Holmgren \& Sheikholeslam (1994) studied the effect of selective grinding on muscle activity in patients with sleep bruxism. They found that the average level of activity of elevator muscles during chewing after occlusal adjustment was increased. This activity was sharper in masseter muscle than in anterior temporal muscle. These authors suggested selective grinding as an alternative treatment.

Kirveskari et al. wanted to prove that there was no difference between the incidence of demand for temporomandibular disorders treatment with regular occlusal adjustment and a treated group regularly simulated. This procedure sought to protect the teeth and periodontal tissue of occlusal loads that result from this pathology and, is an alternative to achieve a harmonious masticatory system.

Sugimoto et al. indicated that in order to prevent the strong activity of bruxism in controlling patterns of grinding, it is necessary to control premature contacts and, thus reduce muscle activity during bruxism, in other words, it is possible to control bruxism by occlusal factors.

This study showed a statistically significant decrease of bruxism episodes in stage 3 sleep $(p<0.01)$, after selective grinding. Macaluso et al. found that $86 \%$ of episodes of bruxism were associated with sleep stages in NO-REM, Similarly to this particular case, where more evident changes were found in stage 3 .

This research also exhibited a statistically significant decrease $(p<0.01)$ of muscle activity in right and left temporal muscles after selective grinding. This situation could be explained by removing interfering contacts, it would allow a homogenous and balanced distribution of muscle forces. After performing selective grinding, muscle contraction improves by mandibular repositioning to a more stable skeletal muscle position (Okeson, 2003). A stable occlusion generates homogeneous or simultaneous mandibular occlusal contacts, which lead to an equitabledistribution of forces. They pass from horizontal to vertical with equal intensity in all teeth that benefits the function of oblique fibers of the periodontal ligament (Goldman, 1968).

Some authors (Kloprogge \& van Griethuysen, 1979; Kawazoe et al., 1980; Türker et al., 2007) suggest that periodontal ligament dissipates loads to the supporting tissues, the mechanoreceptors recover the physiological threshold of excitability and inhibition These make both afferent proprioceptive and inhibitory efferent motor information to be restored Therefore, nonfunctional temporal muscle activity decrease in order to recover contractile function (Kloprogge \& van Griethuysen). The fiber diameter decreases and the number of muscle myofibrils reduces when the 
interferences are removed by selective grinding and, thus resulting in a better load distribution.

Masseter muscle showed a reduction of activity after selective grinding without statistically significant activity before grinding. This finding is consistent with Ingervall \& Carlsson who found that removing occlusal interferences "barely changed" electromyographic patterns of masseter muscles during chewing, postural activity break, and tighten voluntarily in maximal intercuspation position (MIP). They also suggested that whenever a selective grinding was performed, the electromyographic activity showed a slightly reduced result, since occlusal interferences may or may not have negative effects on the muscles. It depends on how a person adapts or reacts to them. Sheikholeslam \& Riise (1983) report that the reduction of muscle activity may be due to inhibition of pain in or around the involved teeth and to spasms removal caused by postural hyperactivity development.

Other authors (Koh \& Robinson, 2003) show that current evidence does not support selective grinding as first-line therapeutic means. This is based on the fact that it is not reversible, and it is limited to certain occlusal patterns. Acosta Ortíz \& Roura Lugo (2009) in a literature review on selective grinding as therapy, states that scientific studies do not clearly support the use or non-selective grinding due to the difficulties in homogeneity of the methodology and design of selective grinding. It is important to consider that occlusal interferences may or may not have side effects on the components of the masticatory system depending on how they influence on the function, or how the person adapts and reacts to them.

The question whether bruxism can be controlled in daily dental practice should be answered in the future, due to the dental an oral problems caused by a strong sleep bruxism. Although some authors agree on that, further research is needed to establish it scientifically (Sugimoto et al.).

\section{CONCLUSION}

After selective grinding the number of episodes of bruxism decreased during sleep stages 2 and 3 cases considered in this study. Selective grinding showed a statistically significant reduction on action potentials recorded by the surface electromyography of the temporal muscle.
RECOMENDATIONS. Unfortunately scientific research on selective grinding as supportive therapy in bruxism is diminishing. Clinical evidence has shown the usefulness of this treatment, therefore it should be considered as there are no definitive conclusive results to date.

Polysomnography and surface electromyography should continue to be used as tests to help in the diagnosis and treatment monitoring in all occlusal therapies for the management of sleep bruxism.

ARISTIZABAL, H. J. A.; RESTREPO, M. F.; PERALTA, P. A. F.; DÍAZ, D. Y. T.; TRIVIÑO, C. A. M.; BALLESTEROS, O. Y. \& YEIMY, P. F. Bruxismo y actividad muscular de maseteros y temporales antes y después de un tallado selectivo. Int. J. Odontostomat., 11(3):253-259, 2017.

RESUMEN: Esta investigación tuvo como objetivo determinar los eventos de bruxismo del sueño registrados por polisomnografía y la actividad de los músculos masetero y temporal registrada por electromiografía de superficie, antes y después de realizar una molienda selectiva. Este estudio comprendió tres etapas: 1. Pre-prueba (evaluación clínica, evaluación a través de articulador semiajustable, polisomnografía y electromiografía); 2 . Molienda selectiva; 3. Post-prueba (polisomnografía y electromiografía). La muestra se conformó de 10 sujetos, que presentaron puntos de contacto prematuros, identificados en una clínica dental. Se evaluaron sujetos entre 21 y 23 años. Ocho sujetos presentaron interferencias posteriores durante los movimientos laterales. Los datos no cumplieron con los criterios de normalidad u homocedasticidad, por lo que se utilizó la prueba de Wilcoxon no paramétrica para comparar los promedios de las variables antes y después. Un promedio de episodios de bruxismo aumentó en las etapas 1 y REM, pero no hubo una diferencia estadística significativa en el registro polisomnográfico después de la molienda selectiva. En las etapas 2 y 3 del sueño, se encontraron $26 \%$ y $54 \%$ de reducciones, respectivamente. En la etapa 3, la diferencia entre los eventos fue estadísticamente significativa. El registro de la actividad electromiográfica antes y después de la molienda selectiva mostró una disminución en la amplitud, longitud y área de los músculos masetero y temporal. La diferencia fue estadísticamente significativa solo para los músculos temporales en los valores de longitud y el área temporal derecha. Después de la molienda selectiva, el número de episodios de bruxismo disminuyó durante las etapas de sueño 2 y 3 . La molienda selectiva mostró una reducción estadísticamente significativa de los potenciales de acción registrados por la electromiografía de superficie del músculo temporal.

PALABRAS CLAVE: bruxismo, polisomnografía, electromiografía, músculo masetero, músculo temporal. 


\section{REFERENCES}

Acosta Ortíz, R. \& Roura Lugo, N. A review of the literature on the causal relationship between occlusal factors (OF) and temporomandibular disorders (TMD) IV: experimental studies of occlusal adjustment by selective grinding as a preventive or therapeutical intervention. Rev. Fac. Odontol. Univ. Antioq., 21(1):98-111, 2009.

American Academy of Sleep Medicine. International Classification of Sleep Disorders. $3^{\text {rd }}$ ed. Darien, American Academy of Sleep Medicine, 2014

Carlsson, G. E.; Egermark, I. \& Magnusson, T. Predictors of bruxism, other oral parafunctions, and tooth wear over a 20-year followup period. J. Orofac. Pain, 17(1):50-7, 2003.

Dawson, P. Evaluation, Diagnosis and Treatment of Occlusal Problems. St. Louis, Mosby, 1974.

De Boever, J. A.; Carlsson, G. E. \& Klineberg, I. J. Need for occlusal therapy and prosthodontic treatment in the management of temporomandibular disorders. Part I. Occlusal interferences and occlusal adjustment. J. Oral Rehabil., 27(5):367-79, 1994.

de-la-Hoz, J. Sleep bruxism: review and update for the restorative dentist. Alpha Omegan, 106(1-2):23-8, 2013.

Goldman, H. Periodontal Theraphy. St. Louis, Mosby, 1968.

Holmgren, K. \& Sheikholeslam, A. Occlusal adjustment and myoelectric activity of the jaw elevator muscles in patients with nocturnal bruxism and craniomandibular disorders. Scand. J. Dent. Res., 102(4):238-43, 1994.

Ingervall, B. \& Carlsson, G. E. Masticatory muscle activity before and after elimination of balancing side occlusal interference. $J$. Oral Rehabil., 9(3):183-92, 1982.

Kardachi, B. J.; Bailey, J. O. \& Ash, M. M. A comparison of biofeedback and occlusal adjustment on bruxism. J. Periodontol., 49(7):367-72, 1978

Kawazoe, Y.; Kotani, H.; Hamada, T. \& Yamada, S. Effect of occlusal splints on the electromyographic activities of masseter muscles during maximum clenching in patients with myofascial paindysfunction syndrome. J. Prosthet. Dent., 43(5):578-80, 1980.

Kirveskari, P. \& Jämsä, T. Health risk from occlusal interferences in females. Eur. J. Orthod., 31(5):490-5, 2009.

Kirveskari, P.; Jämsä, T. \& Alanen, P. Occlusal adjustment and the incidence of demand for temporomandibular disorder treatment. J. Prosthet. Dent., 79(4):433-8, 1998.

Klasser, G. D.; Rei, N. \& Lavigne, G. J. Sleep bruxism etiology: the evolution of a changing paradigm. J. Can. Dent. Assoc., 81:f2, 2015.

Kloprogge, M. J. G. M. \& van Griethuysen, A. M. Disturbances in the contraction and coordination pattern of the masticatory muscles due to dental restorations. J. Oral Rehabil., 3(3):207-16, 1979.

Koh, H. \& Robinson, P. G. Occlusal adjustment for treating and preventing temporomandibular joint disorders. Cochrane Database Syst. Rev., (1):CD003812, 2003.

Kopp, S. Short term evaluation of counselling and occlusal adjustment in patients with mandibular dysfunction involving the temporomandibular joint. J. Oral Rehabil., 6(2):101-9, 1979.

Lavigne, G. J.; Khoury, S.; Abe, S,; Yamaguchi, T. \& Raphael, K. Bruxism physiology and pathology: an overview for clinicians. J. Oral Rehabil., 35(7):476-94, 2008.

Lobbezoo, F.; Ahlberg, J.; Glaros, A. G.; Koyano, K.; Lavigne, G. J.; de Leeuw, R.; Manfredini, D.; Svensson, P. \& Winocur, E. Bruxism defined and graded: an international consensus. J. Oral Rehabil., 40(1):2-4, 2013.

Macaluso, G. M.; Guerra, P.; Di Giovanni, G.; Boselli, M.; Parrino, L. \& Terzano, M. Sleep bruxism is a disorder related to periodic arousals during sleep. J. Dent. Res., 77(4):565-73, 1998.
Manfredini, D. \& Lobbezoo, F. Role of psychosocial factors in the etiology of bruxism. J. Orofac. Pain, 23(2):153-66, 2009.

McHorris, W. H. Occlusal adjustment via selective cutting of natural teeth. Part I. Int. J. Periodontics Restorative Dent., 5(5):8-25, 1985.

Michelotti, A.; Farella, M.; Gallo, L. M.; Veltri, A.; Palla, S. \& Martina, $R$. Effect of occlusal interference on habitual activity of human masseter. J. Dent. Res., 84(7):644-8, 2005.

Okeson, J. P. Tratamiento de Oclusión y Afecciones Temporomandibulares. 5a ed. Madrid, Elsevier, 2003.

Ramfjord, S. P. \& Ash, M. M. Occlusion. Philadelphia, W. B. Saunders, 1966.

Ramfjord, S. P. Bruxism, a clinical and electromyographic study. J. Am. Dent. Assoc., 62:21-44, 1961.

Ruiseco Palomares, A.; Rodríguez Calzadilla, O. L. \& Otaño Laffitte, G. Efectividad del ajuste oclusal en pacientes de alta de ortodoncia. Rev. Cuba. Estomatol., 43(4), 2006.

Sheikholeslam, A. \& Riise, C. Influence of experimental interfering occlusal contacts on the activity of the anterior temporal and masseter muscles during submaximal and maximal bite in the intercuspal position. J. Oral Rehabil., 10(3):207-14, 1983.

Sugimoto, K.; Yoshimi, H.; Sasaguri, K. \& Sato, S. Occlusion factors influencing the magnitude of sleep bruxism activity. Cranio, 29(2):127-37, 2011.

Türker, K. S.; Sowman, P. F.; Tunser, M.; Tuncer, M.; Tucker, K. J. \& Brinkworth, R. S. The role of periodontal mechanoreceptors in mastication. Arch. Oral Biol., 52(4):361-4, 2007.

Vallon, D. Studies of Occlusal Adjustment Therapy in Patients with Craniomandibular Disorders. Lund, Lund University, 1997.

Corresponding author:

Dr. Juan Alberto Aristizabal Hoyos

Universidad Autónoma de Manizales

Antigua Estación del Ferrocarril Manizales

COLOMBIA

E-mail: jaristi@autonoma.edu.co

Received: 31-03-2017

Accepted: 05-07-2017 